\title{
COMMENTARY
}

\section{INTERPRETATION AND AUTHORITY IN STATE CONSTITUTIONALISM}

\section{Paul W. Kahn*}

In 1977, Justice Brennan delivered his now famous plea for a renaissance in state constitutionalism. ${ }^{1}$ As much as any judicial opinion he ever wrote, this plea has influenced the development of American constitutionalism. Since 1977 , there has been an outpouring of scholarly work as well as a renewed interest by bench and bar in the possibilities of state constitutionalism. Conferences are held and papers written in order to encourage its development. ${ }^{2}$

This essay is in the same practical style, advocating a vigorous state constitutionalism. However, I abandon the central premise of most previous works, namely, that the interpretation of a state constitution must rely on unique state sources of law. Those sources include the text of the state constitution, the history of its adoption and application, and the unique, historically identifiable qualities of the state community. State constitutional law, it is assumed, can diverge from federal law only if the differences can be traced to one of these sources. This premise rests on an idea of state sovereignty that at best is a romantic longing for vibrant local communities and at worst misunderstands modern American constitutionalism. My aim is to show that state constitutionalism can survive the abandonment of this premise and that, in fact, the doctrine of unique state sources threatens to undermine the renewed interest in and growth of state constitutional law.

My argument takes the following form. In the first two sections, I present a very brief overview of the contemporary state of federalism and the puzzling appearance of Justice Brennan as an advocate of state constitutionalism. I then elaborate a view of the interpretive character of constitutionalism. In so doing, I distinguish interpretation from truth: constitutionalism is not a single set of truths, but an

\footnotetext{
* Professor of Law, Yale University. The Roscoe Pound Foundation provided support for research on this project. This Commentary is based upon a lecture presented at a forum for state court judges sponsored by the Foundation in July 1992, the proceedings of which have been published as Protecting Individual Rights: The Role of State Constitutionalism (Barbara Wolfson ed., I993).

${ }^{1}$ See William J. Brennan, Jr., State Constitutions and the Protection of Individual Rights, 90 HARV. L. REV. 489, 502-04 (1977).

${ }^{2}$ See, e.g., Symposium: The Emergence of State Constitutional Law, 63 TEx. L. REv. 959 (1985).
} 
ongoing debate about the meaning of the rule of law in a democratic political order. At both the state and national levels, this debate focuses upon the ideas of liberty, equality, and due process, as well as upon the structures of representative government necessary to realize these values. Finally, I consider the relationship between authority and interpretation in constitutional law. Authority is necessary to maintain a political community, but the claim to authority is not itself grounded in interpretation. Authority terminates, but does not resolve, interpretive conflict.

I argue for a state constitutionalism that respects this double distinction of truth from interpretation and interpretation from authority. The diversity of state courts is best understood as a diversity of interpretive bodies, not as a multiplicity of representatives of distinct sovereigns. The common object of state interpretive efforts is American constitutionalism. Each state court has the authority to put into place, within its community, its unique interpretation of that common object. Of course, state courts may not violate United States Supreme Court interpretations of federal law, but beyond this legal floor, federal courts have nothing to say about the way in which state courts exercise their authority to interpret state constitutionalism.

\section{State Constitutionalism and Federalism IN THE MODERN Age}

The doctrine of unique state sources rests upon an idea of the state as a sovereign, independent source of law. If this idea of independence is a necessary premise of a distinctive state constitutional law, then the renewed interest in state constitutionalism does not easily fit within the larger trends in the development of constitutional law. Modern constitutional law, as it has emerged from the federal courts, has generally focused on establishing national political authority on the one hand and protecting the autonomous individual on the other. Both are threatened by a vigorous state authority. Through the centralization of public authority, the individual has been largely freed from the authority of church, ${ }^{3}$ family, ${ }^{4}$ town, ${ }^{5}$ local militia, ${ }^{6}$ unions, ${ }^{7}$

${ }^{3}$ See, e.g., Engel v. Vitale, 370 U.S. 42I, 424-25 (1962) (holding that organized prayer in public schools violates the Establishment Clause).

${ }^{4}$ See, e.g., Planned Parenthood v. Danforth, 428 U.S. 52, 72-75 (1976) (protecting an unmarried minor's access to abortion despite parental objection).

${ }^{5}$ See, e.g., Moore v. City of East Cleveland, 43I U.S. 494, 498-99 (I977) (invalidating municipal zoning restrictions that favored nuclear families).

6 The first federal draft, conscripting men on a nation-wide basis, was enacted during the Civil War. See Act of March 3, 1863, ch. 75, I2 Stat. 731 (1863). See generally JACK F. Leach, Conscription in the United States: Historical Background I62-385 (I952) (discussing the political, legal, and military history of the ${ }^{8} 86_{3}$ Act).

${ }^{7}$ See, e.g., Abood v. Detroit Bd. of Educ., 43I U.S. 209, 234-36 (I977) (holding that public employees cannot be forced to subsidize ideological activities of a union). 
schools, ${ }^{8}$ and political parties. ${ }^{9}$ These traditional forms of local association have come to be seen as nothing more than the products of individual choice. Each is valuable only to the degree that particular individuals choose to participate. State and local communities are seen in the same way: the community is only the aggregate of those individuals who choose to reside in a particular area.

Traditionally, local associations were at the center of public life. This is no longer true: the rise of national political authority has undermined local public associations. The central state has largely captured public life. Local public life is now often identified with prejudice, discrimination, censorship, and ideological rigidity. The individual citizen turns to the national government for protection from these constraints on his or her freedom.

Because public life is experienced in and through the national community, we typically find little sympathy for a local community's effort to maintain a unique public identity. Even the contemporary Supreme Court - despite its renewed interest in federalism ${ }^{10}$ - has had little tolerance for efforts by local communities to treat other national citizens as strangers. ${ }^{11}$ Nor has it had much sympathy for efforts by local communities to take themselves out of the national debate over ideas and values. ${ }^{12}$ If local communities must be wholly open to new entrants and new ideas, they cannot easily defend a historically-realized public identity against cultural, social, and political homogenization.

It is not difficult to identify some of the factors that make the concept of the national citizen who is treated as a local stranger profoundly disturbing today. In the cases, one finds frequent references to national military service as a symbol of a common, that is,

${ }^{8}$ See, e.g., Tinker v. Des Moines Indep. Community Sch. Dist., 393 U.S. 503, 514 (1969) (holding that the First Amendment prevents schools from punishing students who wear expressive armbands).

${ }^{9}$ See, e.g., Branti v. Finkel, 445 U.S. 507, 519-20 (1980) (limiting the reach of political patronage); Elrod v. Burns, 427 U.S. 347, 367-68 (1976) (same).

${ }^{10}$ See, e.g., New York v. United States, I I2 S. Ct. 2408, 24I9-23 (1992) (invalidating on federalism grounds a federal law that compelled states to take title to radioactive waste from private parties).

${ }^{11}$ See, e.g., Fort Gratiot Sanitary Landfill, Inc. v. Michigan Dept. of Natural Resources, I 2 S. Ct. 2019, 2028 (1992) (invalidating a state prohibition on landfill operators accepting outof-county waste); Chemical Waste Management, Inc. v. Hunt, II2 S. Ct. 2009, 2013-I6 (I992) (invalidating a disposal fee levied only on out-of-state waste); Zobel v. Williams, 457 U.S. 55, 65 (1982) (invalidating an Alaskan dividend distribution law that disfavored new entrants into the state by conditioning amounts on years of residence); City of Philadelphia v. New Jersey, 437 U.S. $617,626-27$ ( 1978 ) (invalidating a law that banned the use of waste disposal sites for almost all waste that originated in other states).

12 See, e.g., Pope v. Illinois, 48I U.S. 497, 500-0I (1987) (holding that the "literary, artistic, political or scientific value in allegedly obscene material" must be evaluated under a reasonable person standard and not under a community-specific standard). 
national, public life. ${ }^{13}$ The emergence of a national army has meant that the most intense experience of public life that many people ever have is now oriented wholly toward the nation. Moreover, individuals in the United States are extremely mobile. As individuals lose a geographical focus in their lives, they inevitably turn to the national government as the primary focus of public life. ${ }^{14}$ Similarly, information, ideas, art, and literature are not constrained within geographical boundaries. A national culture and a national media support a national political life. In all of these ways - from defense to art modernity works against federalism.

If states are no longer the locus of a vibrant, community experience, then a state constitutionalism that looks to the unique state community for its sources of decisionmaking promises to remain a marginal factor in American public life. No doubt a good part of the effort to reinvigorate state constitutionalism represents a longing for a resurgence of local communities. But the move toward a national political identity and the emptying of the intermediate associations of public life are not simply consequences of a passing phase of liberal judicial ideology. ${ }^{15}$ A vibrant state constitutionalism must be founded on something other than anachronistic beliefs about state sovereignty as an expression of state differences.

\section{Justice Brennan: Puzzling Prophet of State Constitutionalism}

To those who know Justice Brennan's work, it is a surprise to find him a leading exponent of any position that stands on the doctrine of

${ }^{13}$ See, e.g., Attorney General of New York v. Soto-Lopez, 476 U.S. 898, 9 I I (I986) ("Members of the Armed Forces serve the Nation as a whole."); Hooper v. Bernalillo County Assessor, 472 U.S. 612, 62 I (1985) ("[I]t is difficult to grasp how New Mexico residents serving in the military suffered more than residents of other States who served, so that the latter would not deserve the benefits a State bestows for national military service."); Edwards v. California, 314 U.S. I60, I85 (I94I) (Jackson, J., concurring) (pointing out that national citizenship results in "a duty to render military service").

14 Madison arguably saw the possibility of such a change in popular sentiment when he wrote: "If . . . the people should in the future become more partial to the federal than to the state governments . . . the people ought not surely to be precluded from giving most of their confidence where they may discover it to be most due." THE FEDERALIST No. 46, at 295 (James Madison) (Clinton Rossiter ed., I961).

15 See generally Robert A. Nisbet, The QUest for Community (1953) (arguing that the release of the individual from local associations or communities was a central part of the growth of the modern nation-state). The experience of Western Europeans with the development of the European Community is a good example of the same phenomenon. See Bruce Ackerman, The Future of Liberal Revolution 39-44 (I992) (discussing the possible emergence of European transnational political parties). The ethnic struggle following the collapse of the Soviet Union might appear to be a counterexample, but it is too early to tell whether this effort to decentralize is only a temporary reaction to the extreme centralization of the old Soviet system. 
federalism. Of all the modern Justices, Justice Brennan was probably the least interested in, and the most skeptical of, a vibrant statecentered community life. If modernity works against federalism, he was the quintessential modern Justice.

He was, for example, a strong defender of a constitutional right to travel. ${ }^{16}$ The term "right to travel" is something of a misnomer. The right to travel is not about travel at all; it is about ending travel and taking up residence. It is the right to enter into any local community and upon entry to be treated the same as established members. This right rests on the proposition that local communities have no constitutionally cognizable integrity to be defended against strangers.

The right to travel reflects the primacy of national community membership over local associations. Thus, Justice Brennan located the source of the right not in a particular passage of constitutional text, but "in that document that transformed a loose confederation of States into one Nation." 17 The local community, in his view, has only an instrumental value: "to remedy continuing injustices, to fill current needs, to build on the present in order to better the future."18 Its role is to help individuals achieve their own ends. An individual state is not to concern itself with creating a vibrant, unique community possessing its own traditions: "In almost all instances, the business of the State is not with the past, but with the present . . ."19 The only constitutionally relevant history is national history; as members of the national community, we all share a common history.

Justice Brennan's state constitutionalism was not an acknowledgment of a vibrant, state-centered community life, but rather an attempt to enlist the states in the liberal project of defending the individual against authority: "[S]tate courts [should] thrust themselves into a position of prominence in the struggle to protect the people of our nation from government intrusions on their freedoms." 20 In Justice Brennan's view, this turn to the state courts became even more important as Reagan-Bush appointees came to dominate the federal bench. Thus, by 1986, Justice Brennan summarized the problem as follows:

[T]oday . . . the [Supreme] Court is involved in a new curtailment of the Fourteenth Amendment's scope. . . . [C]ivil and political rights of

${ }^{16}$ See Zobel v. Williams, 457 U.S. 55, 66-68 (1982) (Brennan, J., concurring) ("[W] 'right to travel' is involved, our cases leave no doubt that it will trigger intensified judicial scrutiny."); Shapiro v. Thompson, 394 U.S. 618, 629-31 (1969) (rejecting state minimum residency requirements for welfare benefits on the ground that a right to travel between states is constitutionally guaranteed).

${ }_{17}$ Zobel, 457 U.S. at 67 (Brennan, J., concurring).

18 Id. at 70 .

${ }^{19}$ Id.

${ }^{20}$ See Brennan, supra note $\mathrm{I}$, at 503. 
the individual are treated as inferior to the ever-increasing demands of governmental authority. Although both economic and political power are more intensely concentrated in today's urban industrialized society than ever before, threatening individual privacy and autonomy, we see an increasing tendency to insure control rather than to nurture individuality. ${ }^{21}$

Because the federal bench had shifted its support from individual autonomy to institutional authority, Justice Brennan sought allies who sat on state courts.

Enlisting state court activism in defense of personal liberties might appear to be a clever political move. In order to transport the liberal judicial project outside the jurisdiction of the federal courts, Justice Brennan took advantage of the restraints on federal court activism that his judicial opponents adopted. The problem posed by the contemporary federal courts, however, is not simply jurisdictional. Rather, the problem is an approach to constitutional law that emphasizes the limited legitimacy of judicial decisionmaking and the corresponding need for textual or historical sources to support judicial action. This doctrine not only narrows the reach of the federal courts, but it is likely to have the same effects on the state courts. Convincing the state courts that they should act in the place of the federal courts requires more than an invocation of federalism; it demands an explanation of the grounds of constitutional action that can stand up to the dominant constitutional jurisprudence of the federal bench today. ${ }^{22}$

It is just at this point, however, that Justice Brennan - as well as many who have followed him - is at his weakest. They have accepted the doctrine of unique state sources, under which the authority of the state court is tied to its responsibility to interpret state constitutional text, state history, and the particular values of the state community. Because these sources are unique to each state, they are of no concern to other states or to the national community. The need to find such sources, however, flows out of exactly the same conservative constitutionalism that Justice Brennan seeks to avoid by appealing to state courts.

The doctrine of unique state sources dominates the recent literature. State courts are criticized for their "lapses" when they appeal to federal sources - particularly federal case law. ${ }^{23}$ Much of the

${ }^{21}$ William J. Brennan, Jr., The Bill of Rights and the States: The Revival of State Constitutions as Guardians of Individual Rights, 6r N.Y.U. L. REV. 535, 546 (1986).

${ }^{22}$ See Earl M. Maltz, False Prophet - Justice Brennan and the Theory of State Constitutional Law, I5 HASTings Const. L.Q. 429, 449 (1988).

${ }^{23}$ See, e.g., Todd F. Simon, Independent but Inadequate: State Constitutions and Protection of Freedom of Expression, 33 KAN. L. REv. 305, 316-17 (1985); Edmund B. Spaeth, Jr., Toward a New Partnership: The Future Relationship of Federal and State Constitutional Law, 49 U. PItT. L. Rev. 729, 734-37 (1988); Marshall J. Tinkle, State Constitutional Law in Maine: At the Crossroads, I3 VT. L. REv. 6I, 77-79 (1988). 
debate has focused on the methodological issue of the order in which federal and state sources should be considered: should a state court look first to federal law and only turn to state law if necessary, or should it proceed in the opposite fashion? ${ }^{24}$ That there should be an intersection between state authority and federal sources is ruled out in advance. This intersection, however, is just the position for which I want to argue. It is the position that many state courts find themselves moving toward, ${ }^{25}$ not only because of the meager state sources available, but also because state constitutional debate cannot close its eyes to the larger discursive context within which it finds itself.

\section{INTERPRETATION AND TRUTH in American Constitutionalism}

\section{A. The Changed Character of the Federal Bench}

Although most modern views of the judicial process recognize no sharp separation between the political aspects of government and the work of the courts, a distinction must be made between the rule of law and political interests. These terms define the categories of a debate that undergirds a constitutional order that maintains a dual commitment to the rule of the majority and the rule of law. Critics of judicial decisions will always describe those decisions as failures of law resulting from the corruption of the bench by politics. No one argues for a politicization of the courts; everyone affirms the constraints of law. The real debate concerns the point at which law becomes politics, or conversely, the possibility of transforming politics into law.

The problem with the federal bench today is not that a political agenda has displaced the rule of law. From the perspective of conservatives who have recently controlled the judicial appointment pro-

24 See, e.g., Shirley S. Abrahamson, Reincarnation of State Courts, 36 Sw. L.J. 95 I, 96566 (1982) (arguing for primary reliance on state constitutions to increase diversity and stability of rights); Hans A. Linde, First Things First: Rediscovering the States' Bills of Rights, 90 U. BALT. L. REV. 379, 384 (1980) ("[A] state court should . . . routinely examine its state law first, before reaching a federal issue."); Frank G. Mahady, Towards a Theory of State Constitutional Jurisprudence: A Judge's Thoughts, I3 VT. L. REV. I45, 146-49 (I988) (arguing that state inquiries should precede federal inquiries in state constitutional adjudication).

${ }^{25}$ See, e.g., Kentucky v. Wasson, $84^{2}$ S.W.2d 487, 491-92 (Ky. 1992) (holding unconstitutional, under the state constitution, the criminalization of homosexual sodomy). Here, the Kentucky Supreme Court began by stressing the doctrine of unique state sources, including the structure of the state constitution, as well as original intent and precedent. See id. at 493-96. The opinion moves on, however, to consider the philosophy of John Stuart Mill, the position of the American Law Institute, and the United States Supreme Court's decision in Loving v. Virginia, 388 U.S. I (1967), which struck down state anti-miscegenation statutes. See Wasson, 842 S.W.2d at $496-98$. This led the court to conclude that Bowers v. Hardwick, 478 U.S. I86 (1986), was incorrectly decided. See Wasson, $84^{2}$ S.W.2d at 501. 
cess, the corruption of law by politics had already occurred in the form of the rights-centered activism of the Supreme Court in the I960s and I970s. The conservative members of the Rehnquist Court have aimed to return to "law," the sources of which, in their view, are decidedly narrower than those employed in the decisions of the previous era. ${ }^{26}$

The real problem is that the vision of law's possibilities has become too homogeneous. Not only did Presidents Reagan and Bush appoint a majority of the Supreme Court, but they also appointed more than two-thirds of all sitting federal judges, including a majority on each of the thirteen circuit courts. ${ }^{27}$ The appointees are overwhelmingly male, white, and well off. ${ }^{28}$ More importantly, they share a common political orientation and beliefs about the framework within which constitutional adjudication should occur.

These judges view the judiciary as an undemocratic institution within a political order premised on the idea that governmental legitimacy is derived from the consent of the majority. To overcome this threat of illegitimacy, the courts must stick closely to the tangible products of the political process. In constitutional adjudication, this generally means the text and the original intent of those upon whose authority the legitimacy of the text rests. A court that moves beyond the formalism of text and the boundaries of original history has exited the objective domain of law and has entered the subjective enterprise of politics. When a non-textual constitutional right is of such longstanding recognition that it cannot be abandoned, the Court must base its interpretation on the narrowest possible reading of the relevant tradition. ${ }^{29}$

The application of this changed constitutionalism has yielded dramatic effects. The Supreme Court has moved toward subordinating individual rights to governmental interests in the areas of criminal procedure, ${ }^{30}$ privacy, ${ }^{31}$ equal protection, ${ }^{32}$ free

${ }^{26}$ See, e.g., Planned Parenthood v. Casey, 112 S. Ct. 2791, 2860 (1992) (opinion of Rehnquist, C.J.) (quoting Bowers v. Hardwick, 478 U.S. 186, I94 (I986) ("'The Court is most vulnerable and comes nearest to illegitimacy when it deals with judge-made constitutional law having little or no cognizable roots in the language or design of the Constitution."')).

27 See Eva M. Rodriguez, Federal Judiciary Will Soon Feel Clinton's Stamp, Legal Times, Nov. 9, 1992 , at 13 .

${ }^{28}$ See Joan Biskupic, Bush Treads Well-Worn Path In Building Federal Bench, Cong. Q. WKLY. REP., Jan. I8, I992, at III (arguing that promotion from within leads to this result); W. John Moore, Righting the Courts, NAT'L L.J., Jan. 25, 1992, at 200.

${ }^{29}$ See Michael H. v. Gerald D., 491 U.S. I 10, 127 n.6 (opinion of Scalia, J.).

${ }^{30}$ See, e.g., Payne v. Tennessee, II I S. Ct. 2597, 2609-I I (I99I) (finding no constitutional basis for prohibiting jury consideration of victim-impact evidence in capital cases).

${ }^{31}$ See, e.g., Bowers v. Hardwick, 478 U.S. I86, I90-96 (1986) (upholding a state statute that criminalized homosexual sodomy).

${ }^{32}$ See, e.g., City of Richmond v. J.A. Croson Co., 488 U.S. 469, 509-I I (1989) (invalidating a city's minority set-aside plan). 
exercise, ${ }^{33}$ and procedural due process. ${ }^{34}$ These changes in doctrine illustrate a fundamental point: the mere fact that a doctrine emerges from the authoritative voice of the Supreme Court does not make it correct. The same institutional authority, after all, announced both the new and the old doctrines. Supporters of each doctrine will claim to speak for the law and will accuse their opponents of confusing law and politics. In this debate over the meaning and requirements of law, the Court's voice is never final. Conflicts among interpretations are not resolved by assertions of judicial authority.

When there is only a single view of the possibilities of law, the meaning of the constitutional order is impoverished. A democracy that does not debate the legal boundaries of its own political choices is already failing the constitutional project. ${ }^{35}$ That all sides in this debate will claim to speak for law and against the politicization of the judicial process does not suggest that nothing more than rhetoric is at stake. That a debate has no final answer does not make it meaningless. Most ethical and political questions are not capable of a single, determinative resolution. The indeterminate character of their resolution does not make these questions less pressing. The nation's commitment to a rule of law that protects certain principles and values against political interests presents each generation with a puzzle, not an answer.

To the extent that the interpretive debate within the federal bench has diminished, a new locus must be found for that discourse. In part, that locus is the academy. One role of scholars of constitutional law is to critique the interpretations of the Supreme Court. In part, that locus is Congress, which, as it did in the Civil Rights Act of I99I, can express its disagreement with the Court's interpretations. ${ }^{36}$

Another important locus is the state courts. To the degree that state judges' voices are added to the debate, we should expect a reinvigoration of the discursive ground of a democratic order committed to the rule of law. These voices are likely to enrich the debate not just because they are different, but also because they operate

\footnotetext{
33 See, e.g., Employment Div. v. Smith, 494 U.S. 872, 885-90 (I990) (holding that a state may deny unemployment benefits because of the religiously-inspired ingestion of peyote).

${ }^{34} \mathrm{See}$, e.g., Lassiter v. Department of Social Servs., 452 U.S. I8, 33-34 (I98I) (finding no constitutional right to counsel in parental-rights proceedings).

35 Much of contemporary constitutional theory emphasizes this discursive aspect of American constitutional and political life. See, e.g., Frank Michelman, Law's Republic, 97 YALE L.J. 1493, I5 28-32 (1988).

36 See Civil Rights Act of 1991, Pub. L. No. 102-166, § 2, I05 Stat. 1071, 1071 ("[T] decision of the Supreme Court in Wards Cove Packing Co. v. Atonio, 490 U.S. 642 (I989) has weakened the scope and effectiveness of Federal civil rights protections."). Congress can also express its disagreements with the Supreme Court by declining to enact laws that the Court has indicated it would uphold or by testing the Court's own commitment to an interpretation by enacting laws that put back before the Court issues upon which it has already ruled.
} 
under different institutional constraints. ${ }^{37}$ State court judges often have long-term, but not life, appointments, and they are often subject to some sort of popular check. Their institutional position can be thought of as intermediate between that of federal judges and that of elected representatives. 38

State constitutionalism should not become another vehicle for removing diverse voices from the national debate. Nor should it splinter the debate over the possibilities of the rule of law into a Babel of fifty different communities. That, however, is exactly the effect of the doctrine of unique state sources. At its best, state constitutional discourse can be an interpretive effort directed at the same principles of the rule of law that underlie federal constitutionalism. American constitutionalism is not simply an aggregate of distinct bodies of state and federal doctrine. Rather, American constitutionalism is the interpretive enterprise that seeks to understand the appropriate role for the rule of law in a democratic order.

\section{B. Constitutionalism and the History of Interpretive Diversity}

Approaches to the conflict between the idea of the rule of law and the idea of rule by the majority have changed dramatically over the course of American history. Elsewhere, I have worked out in great detail the paradigm shifts that have characterized the history of American constitutionalism. ${ }^{39}$ Here, I want only to illustrate my general claim that constitutionalism is an interpretive enterprise, not a set of timeless truths.

The earliest meaning of American constitutionalism - that of the Framers and of Chief Justice John Marshall - identified the rule of law with the science of government. The Constitution represented an effort to put into positive legal form the best political science of the day. Although ratification gave popular consent to this product of political science, the text still required an interpretation of that science. For this reason, the great Marshall opinions are dominated by inquiries into the abstract principles of republican political science. ${ }^{40}$

37 Regardless of what may have been true in the past, state supreme court justices are generally acknowledged today to have the professional competence required to participate in a common discourse with federal judges.

38 The recall of Chief Justice Bird and two associate justices of the California Supreme Court provides the most vivid recent example of this intermediate character. See John T. Wold \& John H. Culver, The Defeat of the California Justices: The Campaign, the Electorate, and the Issue of Judicial Accountability, 70 JUDICATURE 348 (1987).

39 See Paul W. Kahn, Legitimacy and History: Self-Government in American Constitutional Theory (I992).

${ }^{40}$ See, e.g., McCulloch v. Maryland, I7 U.S. (4 Wheat.) 316, 426 (I8I9) (describing constitutional inquiry as the specification of "axiom" and deduction of "corollaries"); Marbury v. 
In the period leading up to the Civil War, this idea of constitutionalism as consent to government by and through political science was largely displaced by originalism. Constitutional interpretation looked to the intent of the founding fathers and disregarded claims of scientific truth. ${ }^{41}$ The aim of constitutional government was thought to be the maintenance of the political order brought forth by the Framers' generation. The political community was defined by its particular past, not by abstract principles. There was a widely shared belief that contemporary conflicts could be resolved by returning to the acts and beliefs of the founders.

In the aftermath of the Civil War, the paradigm of originalism gradually lost its dominance. The Framers' failure to create a community that could peacefully sustain itself through affirmation of its origins led to a new understanding of the relationship between the rule of law and the contemporary community. Constitutional theory came to be dominated by the idea of the "unwritten constitution." 42 Unlike the historical text, this constitution could grow with the progress of the nation.

By the turn of the century, this constitutionalism of evolutionary development had merged with the larger common-law tradition. Once again, constitutionalism was seen as a special expression of reason or science - located, however, not in the abstractions of political theorists, but in the special knowledge and techniques of common-law lawyers. The most striking manifestation of this constitutionalism was the development of substantive due process. ${ }^{43}$

The crisis of the New Deal undermined the belief that common law constitutionalism represented a rule of science. Without that belief, this form of constitutionalism appeared simply as another instance of rule by political interests - the interests of a propertied minority. In place of common law science, a new constitutionalism emerged that appealed to majority will. ${ }^{44}$

Constitutionalism in the modern era has again struggled to reconcile the rule of law with the rule of popular interests. The Warren Court responded to the constitutional majoritarianism of the New Deal

Madison, 5 U.S. (I Cranch) I 37, I 76-78 (1803) (discussing the theory of constitutional supremacy that is "essentially attached to a written constitution").

${ }^{41}$ See, e.g., Dred Scott v. Sandford, 60 U.S. (19 How.) 393, 405 (1856) ("The duty of the court is, to interpret the instrument they have framed . . . according to its true intent and meaning when it was adopted."). For an exploration of this theme of originalism in non-judicial sources of nineteenth-century constitutionalism, see Kahn, cited above in note 39 , at 53-58.

42 See, e.g., Hurtado v. California, I IO U.S. 516,529 (1884) (linking interpretation of due process to "progress or improvement"); Christopher G. TIEdeman, THE UNWRitTen Constitution of the United States (I890); Sidney G. Fisher, The Trial of the ConstiTUTION 20 (1862).

${ }^{43}$ See, e.g., Lochner v. New York, I98 U.S. 45, 53, 57-64 (1905).

44 For a classic expression of this view, see Learned Hand, The Bill of Rights (I958). 
with a vigorous defense of the individual as an autonomous, selfdefining agent. ${ }^{45}$ Constitutional governance came to connote the defense of the individual against the majority - a position that continued in the opinions of Justice Brennan.

The present period is marked by two responses to this position. First, we see, particularly on the federal bench, a rejection and a retreat back to the identification of constitutionalism with majoritarianism. ${ }^{46}$ Second, we see in the academy a more complex effort to reconcile the individual with the group; the autonomous act of selfdefinition with the historical community. ${ }^{47}$ The difference between these two responses to the rights-centered constitutionalism of the Warren Court accounts for much of the growing divide between the bench and the academy.

This sketch is not intended to offer a detailed historical analysis, but only to illustrate the changing character of constitutionalism. Constitutionalism is a field of debate, not a settled truth. Constitutional history is rich in resources to join in that debate. For example, it is surprising to learn that at the beginning of this century, the central problem for constitutional theory was the majoritarian - not the counter-majoritarian - difficulty. The question that academics and judges pondered then was not the courts' own legitimacy in a democratic order, but the legitimacy of rule by a majority that, unregulated, threatened little more than mob action. ${ }^{48}$ Constitutionalism at that time was the restraint imposed by the rule of law on the majority's otherwise uncontrolled interests.

The problem of constitutionalism today is to find a discourse that adequately reconciles the individualism of the Warren Court with the majoritarianism that remains the legacy of the New Deal crisis. ${ }^{49}$ Of course, this is simply another way of describing the basic constitutional conflict between the rule of law and the rule of interests, but it captures the contemporary form of this debate. Without reconcilia-

45 See, e.g., New York Times v. Sullivan, 376 U.S. 254, 264-65 (1964) (protecting speech critical of public officials); Sherbert v. Verner, 374 U.S. 398, 406-09 (1963) (holding that the government may not penalize an individual for religious practices).

46 For example, it is no accident that Justice White's opinion for the Court in Bowers v. Hardwick, 478 U.S. I 86 ( 1986 ), in arguing against "judge-made constitutional law having little or no cognizable roots in the language or design of the Constitution," reflected on the schism in the r93os between President Roosevelt and the Court. Id. at I 94 .

47 See Paul W. Kahn, Community in Contemporary Constitutional Theory, 99 YALE L.J. I, 4-7 (1989) (arguing that both interpretive and republican schools of contemporary constitutional scholarship are seeking a new middle ground between the individual and the group).

48 See, e.g., OWen M. Fiss, The RISE of The Modern State i888-igio, at 53-57 (forthcoming I993); TIEDEMAN, supra note 42 , at 80.

49 Bruce Ackerman has articulated a similar idea of the role of synthesis in the interpretation of distinct constitutional moments. See Bruce A. Ackerman, We the People: Foundations I4I-62 (I99I). 
tion, we can expect nothing more than cycles between the idea of individual autonomy and the authority of the majority, between individual rights and majority rights.

The federal bench has moved down the frustrating path of cycles. The resistance of the state courts to follow in lock-step with the federal courts represents a hope to find a middle ground. Whether state courts can go further and help develop an alternative understanding of constitutionalism that reconciles these extremes remains to be seen. Much interesting academic work is being done today in this area; ${ }^{50}$ a state constitutional discourse that pursues this goal of reconciliation would be at the very center of contemporary American constitutionalism. ${ }^{51}$

\section{STAte Constitutionalism AND The INTERPRETIVE ENTERPRISE}

I have made two arguments that now need to be brought together. First, I argued that state constitutionalism should free itself from the constitutionalism of the contemporary federal courts and especially from the doctrine of unique state sources. Second, I argued that constitutionalism is itself an interpretive enterprise that is not bound to a single truth. These arguments intersect at the point at which state constitutionalism is placed within the larger interpretive enterprise of American constitutionalism.

The word "constitution" is ambiguous. It can mean the written document with its unique history, or it can mean the basic values and institutional structures that constitute a particular polity. Not everything in the constitutional text is of "constitutional dimension" and not all that is of constitutional dimension finds its way into text. ${ }^{52}$ Nevertheless, these two meanings tend to come together once the constitution is understood as the object of an interpretive debate. The text is interpreted in light of the larger constitutional commitment to liberty, equality, and due process, as well as an understanding of the meaning of representative government. For example, no state consti-

50 See Kahn, supra note 47.

${ }^{51}$ See Frank I. Michelman, The Supreme Court, 1985 Term - Foreword: Traces of SelfGovernment, IOO HARV. L. REV. 4, 33-36 (1986) (describing the opinions in Goldman v. Weinberger, 475 U.S. 503 ( $\mathrm{I} 986$ ), in terms of a similar effort at reconciliation).

52 In this essay, I am concerned only with those aspects of a state constitutional text that are of "constitutional dimension." Generally, this means the constitutional protections of liberty, equality, and due process, as well as the structuring of political institutions that aim simultaneously to realize these values and to represent constituent interests. The state constitutional text may contain a great deal that does not rise to this level. Such items may be unique to each state and need not be considered part of the general enterprise of American constitutionalism. 
tution is indifferent to the principle of equality, even if the state text does not have an equal protection clause. ${ }^{53}$

The doctrine of unique state sources is an approach to constitutional interpretation that rests upon two unexamined assumptions. First, it assumes that differences in the narrow constitution - the formal text and its history - of each state reflect differences in each state's larger constitution. Second, it assumes that constitutional adjudication is a matter of presenting what already exists within those state sources. Both assumptions reflect a fear that the only alternative to an interpretation based upon unique state sources is national uniformity. Interpretive diversity within a common enterprise, however, represents a third possibility that dissipates the fear and undermines the assumptions.

Constitutional discourse is the inquiry into the legal boundaries of majoritarian choice. This inquiry is, in part, an effort to articulate those values that stand behind a rule of law - equality, liberty, and due process - and, in part, an effort to understand the institutional structure of a polity simultaneously committed to law and majoritarianism. These subjects are the common heritage of constitutionalism in the United States. They inform constitutional debate wherever it occurs - among judges, academics, politicians, or ordinary citizens. State constitutional texts are best thought of as multiple efforts to articulate a common aspiration for constitutional governance.

To rest state constitutionalism on an idea of the state as an alreadydefined historical community, with a text that can be interpreted to reflect the unique political identity of members of that community, is to try to build a serious legal doctrine on what may be no more than an anachronism or romantic myth. Methodologically, the doctrine is backwards: as the subjects of debate become more difficult, the need to be open to the widest possible sources increases. Substantively, it would be remarkable if the authors of each of these state sources assuming it even makes sense to speak of authors - had resolved and codified distinct answers to our common constitutional problems. ${ }^{54}$ Even if they had, given the mobility and changing character of today's citizens, ${ }^{55}$ there is no reason to believe that there is a substantial coherence between the actual community's values and

53 See, e.g., Hans Linde, Are State Constitutions Common Law?, 34 ARIZ. L. REV. 2 I5, 220 (1992) (discussing the New Jersey Supreme Court's use of due process and equal protection principles despite the absence of textual provisions in its state consitution).

54 See James A. Gardner, The Failed Discourse of State Constitutionalism, $90 \mathrm{MICH}$. L. REv. 76I, 828 (1992) (describing the "collapse of meaningful state identity and the coalescence of a social consensus that fundamental values in this country will be debated and resolved on a national level").

55 See, e.g., Felicity Barringer, Portrait of America: New Census Data Reveal Redistribution of Poverty, N.Y. TIMES, May 29, I992, at AII, AI4 (reporting that recent census data shows that a high percentage of the national population was not born in the state of residence). 
those sources. The doctrine, in short, assumes its own legitimacy. Instead of recognizing that diversity grows out of interpretive activity, the unique state sources doctrine seeks to locate diversity in substantive differences localized in time and space.

Neither judge nor commentator can escape the responsibility of interpretation. No source or set of sources will simply present an answer. The object of interpretation might, for example, be the meaning of the constitutional value of equality. Equality does not have a single, definite meaning in any community prior to the process of interpretation. It is not a thing waiting to be discovered by a judge. It only has an identifiable shape after the judge articulates the conclusion of an interpretive inquiry. Even that conclusion is only a momentary stopping point in an ongoing debate. In this debate, it is not possible for a judge - or anyone else - to consider the meaning of equality without drawing on a wealth of experiences, arguments, and values that range across local, national, and even international communities.

There is no way to exclude these factors from the interpretive process, nor should we want to. The effort of each judge should be to construct the best interpretation of equality of which he or she is capable. ${ }^{56}$ The inquiry might turn to any number of texts, precedents, or historical events, as well as moral intuitions and principled arguments. The best interpretation is that which achieves the greatest harmony among these diverse sources. We distort this process if we conceive of it as an effort to put into place a local community's unique concept of equality, instead of the constitutional goal of equality that is a common aspiration of American life. The same can be said of liberty, due process, and the other broad values of our constitutionalism.

Of course, different courts can and will reach different conclusions about the meaning of such constitutional values. Agreement is no more to be expected of courts than of individuals. Conflict over the meaning of common values, however, does not imply that each community has hold of a unique or separate constitutional truth. There is not one equality in Connecticut and another in Texas, or even Utah. Differences reflect the rich possibilities of interpretation. These are differences that each state must engage and discuss - and not simply dismiss as arising from unique state sources. Abandonment of the doctrine of unique state sources hardly suggests homogeneity in the interpretive enterprise.

Conflicts of interpretation may reflect variations in state experience with respect to a particular value, just as differences in personal tation).

56 See RoNAld DWORKIN, LAW's EMPIRE 255-56 (I986) (developing idea of "best" interpre- 
experience lead to different moral insights. Different state understandings of constitutional norms should similarly be seen as different insights into a common object of interpretation. No state's experiences are so different as to reject the norms of equality, liberty, and due process as the ideals of the constitutional order. No state is so unique that it has neither anything to say to, or learn from, other states.

These arguments about the character of constitutional interpretation proceed independently from the quite questionable legitimacy of an originalist methodology as an approach to state constitutionalism. Originalism is only a particularly narrow version of the doctrine of unique state sources. It proposes to base interpretation of the state's constitutional text on the intent of the framers and/or ratifiers of that text. Unlike the Framers of the federal Constitution, however, the very identity of the state framers is often unknown, and even less is known of their beliefs. More importantly, sizeable numbers - often a majority - of a state's residents do not consider themselves members of a tradition of participation in a state community that reaches back to that founding. Although there are substantial problems with originalism as an interpretive approach to the national Constitution, ${ }^{57}$ at least membership in the national community involves education in national history and an appreciation of the unique character and values of the Framers and the text they produced. ${ }^{58}$ Neither proposition is true with respect to the states. To advocate an originalist approach to state constitutional law is to present state judges with a nearly impossible task of questionable legitimacy.

My argument that constitutional interpretation by the different state courts has a common object in American constitutionalism is very similar to the views of Thomas Cooley, the most important constitutional theorist of the second half of the nineteenth century and a Justice on the Michigan Supreme Court. Cooley believed that state constitutionalism could be explained in a single treatise, organized by substantive topics. ${ }^{59}$ It did not require a separate handbook covering each state's text and history.

57 See, e.g., Ronald Dworkin, The Forum of Principle, 56 N.Y.U. L. REv. 469, 471-500 (I98I).

58 Some scholars claim that the greater ease by which state constitutions can be amended, as well as their more recent vintage, makes an originalist approach to their interpretation more justifiable than with respect to the federal Constitution. See, e.g., Vito J. Titone, State Constitutional Interpretation: The Search for an Anchor in a Rough Sea, 6I ST. JoHN's L. REv. 431, 462 (1987). But cf. Peter R. Teachout, Against the Stream, 13 Vt. L. REv. 13, 26-34 (I 988 ) (complaining about the lack of historical materials for state courts to use in constitutional interpretation). Even Judge Titone is not convinced of the adequacy of originalism as an interpretive methodology. See Titone, supra, at 463-64 (suggesting a "more eclectic approach" than pure originalism).

59 See Thomas M. Cooley, A Treatise on the Constitutional limitations Which Rest UPON the Legislative Power of the States of the American Union at $v$-xvi (4th ed. 1878$)$. 
Cooley looked to the cases coming from the different state courts to find the common principles of state constitutionalism - and, ultimately, of American constitutionalism. ${ }^{60}$ Just as his contemporaries looked to the case law from different jurisdictions to find the common principles of tort or contract, ${ }^{61}$ Cooley aimed to describe an American constitutionalism that was the common object of each state court's interpretive effort. The diversity of state courts, each claiming a unique authority, did not prevent their engagement in a common interpretive enterprise.

Cooley's idea of a common constitutional order, independent of any particular state's formal text, history, and precedents, can be separated from two other ideas that he brought to his work. First, he believed that because there is a common object at which the diverse state courts aim, that object must itself be fully articulable through a scientific inquiry. His treatise aspired to be the scientific presentation of that which the case law approached only in a disorganized and unscientific manner. Cooley was wrong to believe that an inexhaustible interpretive diversity would undermine the coherence of the interpretive enterprise. Debate over the appropriate interpretation of equality, for example, does not become meaningless once we abandon the idea that there is a single objective form of equality.

Second, Cooley identified constitutionalism with the common law. Constitutional decisionmaking by the courts was only a continuation of the ancient practice of common-law decisionmaking. Cooley rightly perceived connections between constitutional discourse and more general efforts of legalism, but erred in thinking that this legal development across generations could be brought to an end. The common enterprise of interpretation is held together by a common discourse, not by a single telos.

Nevertheless, Cooley's basic insight remains valuable. State courts should be talking with each other, as well as with the federal courts and even with academics. All are engaged in a search for the meaning of common concepts. The unique authority of each does not speak at all to the common substance of their interpretive effort.

\section{Distinguishing the INTERPREtive TASK FROM THE AUTHORITATIVE VOICE}

Interpretive diversity is the ordinary way in which we experience constitutional meanings. Only occasionally does a court speak au-

60 Cooley elaborates the same substantive principles of constitutionalism in a chapter interpreting the Fourteenth Amendment, which he included in his edition of Justice Story's Commentaries. See Joseph Story, Commentaries on the Constitution of the UNITEd States 648-85 (Thomas M. Cooley ed., 4th ed. 1873).

61 See, e.g., C.C. Langdell, A Selection of Cases on the Law of Contracts at viiiix (187I). 
thoritatively to a constitutional controversy. Most obviously, a constitutional question can only come before a federal court if it is necessary to the resolution of a case or controversy. Even when a constitutional issue is in litigation, it can take many years to reach a final resolution. When a court does speak, its pronouncement rapidly becomes only another text that is again subject to interpretive diversity. More speech can never end the diversity of the interpretive enterprise. Constitutions inform a ceaseless discourse that constantly exceeds jurisdictional boundaries and the possibilities of judicial authority.

Nevertheless, every community must have the capacity to stop talking and to act. Because a political community is not just a debating society but an historical actor, it must locate within itself an authority to decide. A society may, therefore, contain substantial interpretive conflict over its values and the meaning of its legal rules, while simultaneously maintaining substantial agreement about the authority of particular institutions to resolve these conflicts. The hierarchical organization of the courts, for example, represents just such a combination of interpretive diversity within a generally agreed upon structure of authority. Appellate courts do not differ from lower courts in the character of their interpretations but rather in the nature of their authority. Higher courts have no greater access to truth, only power. ${ }^{62}$

Although authority does not rest on the correctness of its interpretations, it makes a good deal of difference whether or not an authority understands itself as bound by a truth outside of itself. Authority in a constitutional order is not the unconstrained power to resolve interpretive controversy, but the power to put in place an interpretation that the decisionmaker believes to be the best. ${ }^{63}$ Authority that no longer considers itself bound by interpretation becomes merely a power to coerce. Authority that is committed wholly to interpretive truth could never act.

Although I argue for interpretive diversity, I do not challenge the authority of the United States Supreme Court to exercise its authority over state court interpretations of federal law, including the Constitution. This principle, established in Martin $v$. Hunter's Lessee, ${ }^{64}$ represents just the sort of reconciliation of interpretation and authority that I described above: diverse communities and institutions of interpretation recognize the need for an authoritative voice. The authority of the Court does not rest on the truth of its interpretations. Indeed, just the opposite is the case: because truth cannot provide a standard

\footnotetext{
62 See Brown v. Allen, 344 U.S. 443, 540 (1953) (Jackson, J., concurring in the result) ("We are not final because we are infallible, but we are infallible only because we are final.").

${ }^{63}$ See supra p. I161.

64 I4 U.S. (I Wheat.) 304 (1816).
} 
by which to select among diverse interpretations, authority is required. Authority is not grounded on interpretation, but on political necessity. Power holds together a community in the face of a diversity of meanings. ${ }^{65}$

As interpreters of the national Constitution, state courts are not situated differently from lower federal courts: all are subject to the authority of the United States Supreme Court. To know the character of federal court authority over any given case of state court adjudication, however, it is not enough to know the sources of interpretation deployed by the state court. If authority does not derive from interpretation, courts engaged in similar interpretive enterprises are not necessarily subject to the same authoritative voice. For example, a state may adopt its formal constitutional text directly from the federal text. It does not follow, however, that state court interpretations of that text are subject to the authority of the United States Supreme Court. ${ }^{66}$ That a state court is interpreting an object that has its source in federal law does not, of itself, subject it to the authority of the federal courts.

A state court is subject to federal court review only when it is operating as an instrumentality of federal authority. Whether a state court is acting as such an instrumentality depends in large part upon the self-understanding of the court: does it understand the coercive authority - not the truth - of its decision to arise from its place within the structured institutions of federal authority? It does not matter how it gets into this position. For example, it may have no choice when a litigant raises a federal claim that would prevent the full operation of state law. All that matters is the source - national or state - of the power to require compliance with a judicial interpretation. ${ }^{67}$

The authority of the state courts to resolve a dispute comes, therefore, from two distinct sources: state and federal. This is a distinction that matters not when we ask about the interpretation of law, but

65 See generally, Robert M. Cover, The Supreme Court, 1982 Term - Foreword: Nomos and Narrative, 97 HARV. L. REV. 4, I6 (1983) ("It is the problem of the multiplicity of meaning - the fact that never only one but always many worlds are created by the too fertile forces of jurisgenesis - that leads at once to the imperial virtues and the imperial mode of world maintenance.").

66 See Joseph R. Grodin, Some Reflections on State Constitutions, 15 Hastings Const. L. Q. 391, 40I-02 (1988) (discussing the California Supreme Court's decision in People v. Houston, 724 P.2d I 66 (Cal. 1986), not to follow the federal Supreme Court interpretation's of similar text); see also Robert F. Williams, In the Supreme Court's Shadow: Legitimacy of State Rejection of Supreme Court Reasoning and Result, 35 S.C. L. REv. 353, 403-04 (1984) (characterizing state court's reliance on the decisions of the United States Supreme Court as "misplaced" and "an unwarranted delegation of state power to the Supreme Court").

${ }^{67}$ Similarly, the fact that a federal court interprets a state-law rule does not subject it to the authority of the state courts. Its power to coerce continues to derive from federal authority. 
about the authority of an interpretation. A state court that rests its authority on federal power is subject to the power of federal institutions to coerce compliance with an interpretation with which it may disagree. State constitutionalism begins when federal authority ends, not when the use of federal sources ends. ${ }^{68}$ To decide a case under federal law is not merely to interpret federal sources of law, but to place the court and the parties within the structure of federal authority.

Thus, nothing follows about the character of the interpretive task from the fact that a state court relies upon its authority as an institution of the state political community. The appropriate object and character of interpretation still must be specified. I argued above that a realistic appraisal of the nature of constitutional inquiry in a democratic polity as well as of the nature of contemporary state communities provide substantial grounds for taking the object of that interpretation to be American constitutionalism.

On my view, each state constitution represents, in large measure, an effort to realize within the bounds of a particular time and space a common ideal of American constitutionalism. The states share a common aspiration for constitutional governance. Although some states may have been founded to secure a place for difference from existing political communities, most states were founded not in order to be different, but to realize for their own communities the ideals that are the common heritage of the nation. Whatever the differences in historical origins, those differences are less and less relevant to today's communities. ${ }^{69}$

State courts are uniquely placed to contest the meaning of membership in the American polity. Although authority does not itself provide a ground of truth, authority exercised responsibly is a ground for respecting an interpretation. A state court interpreting American constitutionalism is, therefore, a powerful counterforce to federal court interpretation of the United States Constitution. The explanation of American citizenship is too important a task to leave to the federal courts alone.

This state-court function accords with a longstanding justification of federalism under which state governments provide a forum for discussion, disagreement, and opposition to actions of the national government. ${ }^{70}$ To the degree that state courts interpret the federal

\footnotetext{
${ }^{68}$ For the opposite view, see, for example, Mahady, cited above in note 24 , at 149 , who describes the link of state-court authority to unique state sources as "obvious."

${ }^{69}$ See supra pp. I148-50.

70 See Akhil R. Amar, Of Sovereignty and Federalism, 96 YALE L.J. I425, I500-03 (1987). The classic example of this opposition was the responses of the Virginia and Kentucky Resolutions to the federal Alien and Sedition Acts, which "effectively transformed the national election of 1800 into a popular referendum on these bills." Id. at 1502 .
} 
Constitution as such, they are subject to the authority of the United States Supreme Court. To the degree they interpret their own constitutions under the doctrine of unique state sources, their interpretations fail to make contact with those of the federal courts. Only a constitutional federalism that recognizes an ideal of American constitutionalism can make the state courts a powerful measure by which to evaluate the constitutionalism of the federal bench.

\section{Conclusion: The Doctrinal Possibilities FOR A NEW CONSTITUTIONAL FEDERALISM}

Michigan $v$. Long ${ }^{71}$ put into place the doctrinal scheme within which the state-court pursuit of American constitutionalism can proceed. Rejecting prior approaches to the question of determining when a state court judgment rests on "adequate and independent state grounds" - and thus precludes federal court review - the Supreme Court adopted a plain statement rule: "If the state court decision indicates clearly and expressly that it is alternatively based on bona fide separate, adequate, and independent grounds, we . . . will not undertake to review the decision." 72

The Court created a presumption that "adequate state grounds are not independent unless it clearly appears otherwise [in the opinion]."73 This presumption appears to create the possibility of greater federal intrusion in state court decisionmaking. In reality, the decision creates a formulaic method by which a state court can effectively insulate its decision from Supreme Court review, regardless of the sources it uses in reaching its interpretation of the state constitution. ${ }^{74}$ To preclude federal review, the state court need only include in its opinion a formal statement that it is exercising state, not federal authority. ${ }^{75}$

The problem of Michigan $v$. Long was created by the fact that state courts regularly turn to federal sources of law in explaining their decisions. State court opinions range widely over both federal and state precedents in interpreting claims of constitutional right. The Court's concern was to distinguish between the state court that "used federal law to guide [its] application of state law," 76 and the state

${ }^{71} 463$ U.S. 1032 (1983).

72 Id. at $104 \mathrm{I}$.

${ }^{73}$ Id. at 1066 (Stevens, J., dissenting).

74 Of course, a state-law decision is not independent in the sense that it may itself be challenged as violating federal constitutional rights.

75 See, e.g., State v. Ball, 47 I A.2d 347, $35^{2}$ (N.H. 1983) ("We hereby make clear that when this court cites federal and other State court opinions in construing provisions of the New Hampshire Constitution or statutes, we rely on those precedents merely for guidance . . . ."); Yvonne Kauger, Reflections on Federalism: Protections Afforded by State Constitutions, 27 Gonz. L. REV. I, I3 (I99I) (describing the "magic words" doctrine of Michigan v. Long).

76 Long, 463 U.S. at 1039. 
court that reached its decision under the belief "that federal law required it to do so." 77 The distinction flows from the grounds of authority, not from the sources of interpretation. The resolution of Michigan $v$. Long looks to the state court's self-conscious attribution of the source of its authority. Michigan $v$. Long effectively frees a state court to build its interpretation upon the best sources of argument, wherever it might find them. ${ }^{78}$ The decision, therefore, provides the doctrinal opening for interpretive diversity of a common constitutionalism.

After Michigan $v$. Long, a state court is free to pursue a single discussion of the meaning of constitutionalism. The mere fact that a constitutional interpretation looks to federal sources of law does not place the state court under the authority of the United States Supreme Court. State court interpretation of those sources remains independent of the authority of the United States Supreme Court, as long as the state court recites the Michigan v. Long formula.

The state constitutionalism I envision is a process of giving voice to the state court's understanding of the values and principles of the national community. State court interpretations of federal sources of law are not simply dicta. These sources are an integral part of the decision; they support the holding. The authority of the holding, however, does not come from these sources. Authority never comes from interpretation. Interpretations of federal sources are neither dicta nor a binding rule of action for courts in other jurisdictions. Their status is somewhere in between - a status comprehended in the respect due an interpretation for which responsibility is taken.

If we free the state courts to place themselves in the tradition of American constitutionalism, instead of in the narrow parochialism of traditional federalism, then the meaning of American citizenship is enriched. It is enriched whenever new voices are added to the debate over the meaning of the rule of law within a democratic polity. It is especially enriched because fifty different courts will talk with each other, as well as with the federal courts, about the meaning of a common enterprise. In this way, constitutional federalism becomes a means of enriching all of the members of the national community and of binding each of the states to the others. This federalism can make of us a better national community. It need not divide us from each other.

\footnotetext{
77 Id. at $104 \mathrm{I}$.

78 See supra p. II6I.
} 